\title{
岸壁直前に設置した海上防災基地の津波 に対する模型実験 \\ MODEL TEST OF AN EMERGENCY FLOATING FACILITY POSITIONED IN FRONT OF A QUAY WALL AGAINST TSUNAMIS
}

\author{
山本和宏 1 - 関田欣治 2 \\ 井口高志 ${ }^{3} \cdot$ 林辰樹 4 \\ Kazuhiro YAMAMOTO, Kinji SEKITA \\ Takashi IGUCHI,Tatsuki HAYASHI
}

\author{
1正会員＼cjkstart株式会社 ライテック（テ162-0845 東京都新宿区市谷本村町2番7号） \\ 2正会員 工博 東海大学 海洋学部 海洋土木工学科 (テ424-8610 静岡県清水市折戸3-20-1) \\ 3 正会員 株式会社 海洋河川研究所（テ160-0023 東京都新宿区西新宿7-18-5 中央第 7 西新宿ビル） \\ 4 学生会員 東海大学大学院 海洋学研究科 海洋工学専攻（广424-8610 静岡県清水市折戸 $3-20-1$ )
}

\begin{abstract}
As became clear in the Hansin/Awaji earthquake of Jan.17, 1995, the access from the sea to the areas struck by disasters may be an effective alternative way for emergency and first aids. Therefore we proposed the design concept for a permanent floating emergency facility through the quay or wharf of areas suffered from the natural disaster such as earthquakes at the symposium of Civil Engineering in the Ocean last year. It was a kind of floating structure such as a Quick Installation Platform (QIP) or a self-elevating platform for Shimizu port in Miho bay where a tsunami up to 4 meters is expected as a result of the likely Tokai earthquake. In order to confirm our concept from a viewpoint of safety such as deck wetness, stability of the structure against tsunami forces, we conducted a 1/38 scale model test in both (usual) semi-floating and (unusual) lifted condition. In consequence, it turned out that the facility couldn't stand for the tsunami up to 3 meter in the semi-floating condition; therefore it is necessary to elevate the deck to avoid tsunami forces. To do this, the deck must be elevated during arrival time to the facility from the epicenter.
\end{abstract}

Key Words: Disaster prevention, floating facility, earthquake, quick installation platform, tsunami

\section{1.はじめに}

阪神・淡路大震災では、陸上交通の麻瘏と港湾の 決壊により緊急救援物資の供給体制が十分機能しな かった。もし陸部に防災支援基地があったとしても 陸上交通のダメージにより、その施設は孤立を免れ ず十分な支援ができたか分からない.そこで陸部の 混乱を受けない独立型の施設「海上移動式防災支援 基地」 ${ }^{1)}$ が有効と考えられる.

そこで我々は静岡県という地域で、防災施設とし ての浮体構造物利用を検討している. 静岡県の特徵 のひとつとして、伊豆の東方沖地震や東海地震の発 生の可能性が指摘されている地域であることから地 震防災への対応可能な施設が不可欠である.そこで 海上からの支援や長野県等の側からの航空手段によ る救援が有効となるのは明確である.このような基
地は、静岡県が進めている各種の防災施策を補完し、 被災直後からの被災者に対する救援活動及び外部か らの救援に対する迅速な対応を図ることができる.

本基地は着底式構造物と浮体式構造物の,メット を生かした半浮体式構造物を用いており、係留装置 はQIP ${ }^{2)}$ Quick Installation Platform)を採用して いる、QIPを用いた杭式海洋構造物は、受ける波力 や流れに対する力が小さく、経済性にも優れ、また 環境にも優しい，現在検討されている海上防災支援 拠点構想の防災基地は、被災後数日かかってタグ ボートにより曳航されてくるものであるが、我々の 提案する防災基地は常設型であり、被災後すぐに支 援できるものである.

大規模浮体の孤立波 (津波) に対する安全性実験を 実施し、津波の周期が長く、波高の大きくない場合 には問題のないことが解明されている ${ }^{3)}$ が、小規模 で清水港のような複雑で湾内振動が起こり、数 $\mathrm{m}$ と 
大きな津波が来るような地点に浮体を設置するのは 難しいと思われる．そこで係留と支持を脚と浮力に よる半浮体方式ならば可能性があると考え、これを 実験により調べた.

静岡県の特定重要港湾である駿河湾内清水港に本 基地を設置すると想定し、清水港清水市岸壁とQIP 式構造物の $1 / 38$ 縮尺模型を用いてこれらの構造物に 津波を作用させ、どのような影響を受けるかを調べ た.

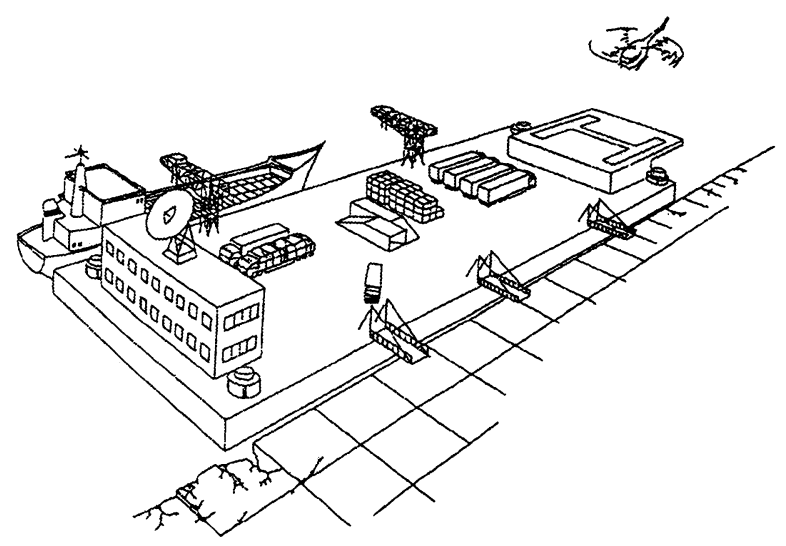

図-1 海上防災基地

\section{2. 海上防災基地のコンセプト}

\section{（1）常設型の海上防災基地}

本基地は自己昇降式の係留装置QIPのような脚式 係留装置を装備し、ており、津波来壟時の非常時には、 基地本体を上昇させて回避することができる，この 装置により常に災害非常時の使用に待機することが できる清水港に常設の基地であり、これが大きな特 徵である. 平常時の使用に関しては、催事場、防災 啓蒙施設などに一般利用し、地震発生後の津波来襲 の際には、救援・復旧作業にすばやく対応すること ができる. 現在実行中や計画されている防災支援拠 点構想の防㷋基地とはここが異なる点である.

\section{（2）海上防災基地運用システム}

本基地は、駿河湾遠方沖合に設置した地震セン サー、海底に取り付けた加速度計、または気象庁か らの地震発生情報を受け、 5 分から 6 分の間で基地 本体をすばやく上昇する。こうすることにより浮体 部を津波最高位より若干高い位置にし、津波を回避 する。

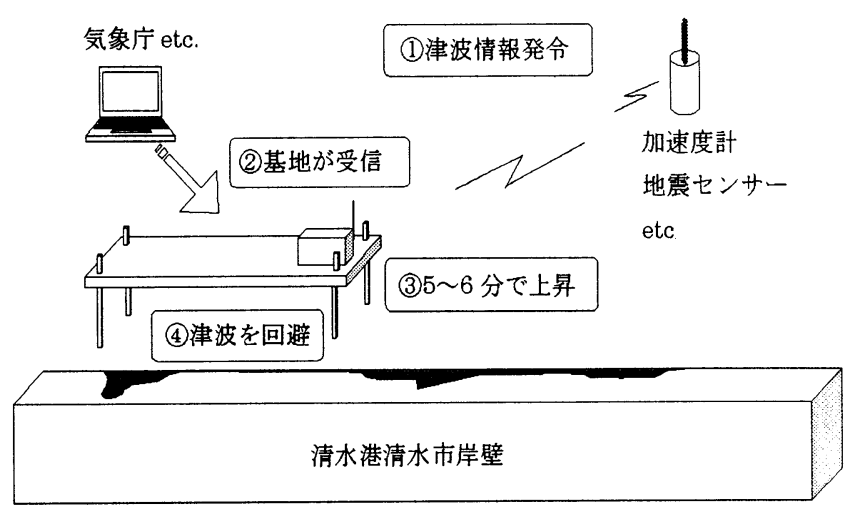

図-2 津波来襲時の防災基地の運用図

\section{3. 研究目的}

前述の海上防災基地の設置海域を静岡県清水港清 水市岸壁に設置すると想定し、この海域の津波来襲 時において以下のような目的で基地本体の挙動を調 ベる.

二次元水槽において清水市岸壁およびその直前に 設置した本基地を $1 / 38$ 縮尺に設定し、津波を作用 させて実験する.

（1）本基地は平常時の半浮体時には脚と浮力で自重 を支える格好になっている.また非常時には本体 を上昇させて、脚だけで自重を支えるようになっ ており、その両状態において津波が本基地に及ぼ す影響をその際の波高、流速、基地本体にかかる 津波力から調べる.

(2) 平常時には半浮体状態であり津波来襲時には上 昇状態である本基地のコンセプトの確認をする.

\section{3．実験条件および実験方法}

（1）実験装置および海上防災基地モデル

実験はボールネジ駆動式造波装置を装備した東海 大学臨海実験場の二次元水槽 (長さ $38 \mathrm{~m} \cdot$ 幅 $1.0 \mathrm{~m} \cdot$ 高 さ0.6m)を用いて行った.

海上防災基地モデルは、実機では $150 \mathrm{~m} \times 50 \mathrm{~m} \times 6 \mathrm{~m}$ の ものを想定している．今回実験水槽の寸法、性能等 の制約から本実験の縮尺を $1 / 38$ (フルード則適用) と し、奥行き $1330 \mathrm{~mm}$ 、幅 $800 \mathrm{~mm}$ 、高さ $80 \mathrm{~mm}$ のものを使 用している.

\section{（2）実験条件}

津波として孤立波を作用させて実験を行っている (以下津波と呼ぶ). 実際の水深は $12.24 \mathrm{~m}$ で、モデル 上では $32.2 \mathrm{~cm}$ としている津波波高については、清 水港で予想される実際の津波が3.0mであることから、 モデル上では $7.9 \mathrm{~cm}$ 中心に $3.9 \mathrm{~cm}$ から実験を行って いる.

また、ここでの見掛け周期とはGoringが提唱する 
津波の見掛け上の周期 ${ }^{4)}$ を指し、孤立波が通過する 時間を言う。なお実際の津波の見掛け周期は20〜30 分から 1 時間程度となるが、今回の実験では造波機 の性能や水槽の長さ等から、最大 16.2 秒で実験をし た.そして比較検討するために、種々の見掛け周期 に対しても行っている。

表-1 津波波高の条件

\begin{tabular}{|c|r|}
\hline 物理量 & 模型実験 \\
\hline & $\mathrm{Hm}=3.9 \mathrm{~cm}$ \\
& $=5.3 \mathrm{~cm}$ \\
& $=6.6 \mathrm{~cm}$ \\
& $=7.9 \mathrm{~cm}$ \\
津波波高 & $=9.2 \mathrm{~cm}$ \\
& \\
& \\
\hline
\end{tabular}

\begin{tabular}{|c|c|}
\hline \multicolumn{2}{|c|}{ 表-2 見掛け周期の条件 } \\
\hline 物理量 & 模型実験 \\
\hline & $\mathrm{T} \mathrm{m}=3.2 \mathrm{~s}$ \\
& $=6.5 \mathrm{~s}$ \\
& $=9.7 \mathrm{~s}$ \\
& $=13.0 \mathrm{~s}$ \\
見掛け周期 & $=16.2 \mathrm{~s}$ \\
& \\
\hline
\end{tabular}

\section{（3）平常時および非常時の基地の設置}

本基地の平常時(半浮体時) は、自重を浮力と脚に より支える格好になっており、図-3のような状態で ある。実験は半浮体状態での挙動について調べてい る.

a) 平常時の浮体模型（半浮体状態）

このとき喫水 $12 \mathrm{~mm}$

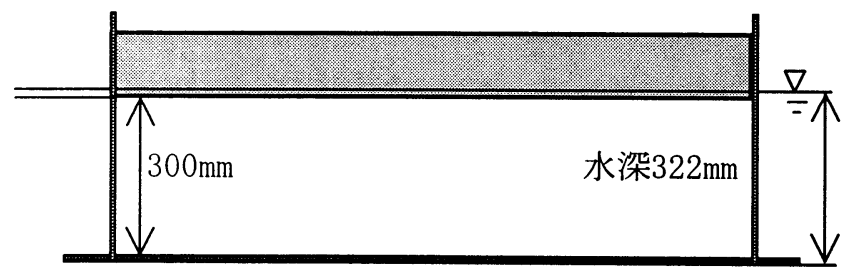

図-3 浮体模型の設置状況（平常時）

b) 非常時の浮体模型（上昇状態）

これけ浮休本休を上昇させて津波を回避する上き の状態である。このタイプ(図-4) は脚のみで自重を 支えているが、基地本体が大きな影響を受けるよう な津波力は作用しないことが実験より分かった.

喫水なし、デッキクリアランス $78 \mathrm{~mm}$

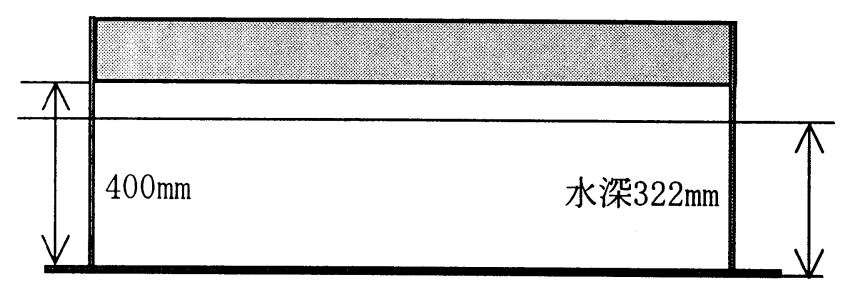

図-4 浮体模型の設置状況（非常時）

\section{(4) 計測項目}

今回の実験では、本基地に作用する津波力などを 明らかにするために以下に示す項目について計測を 行った.

a)波高:津波波高が岸壁直前で、どのように変化し ているのかを調べるために、波高計を造波機 直後、模型前面の模型から $56 \mathrm{~cm}$ 前と直前 $30 \mathrm{~cm}$ の計3ヶ所に設置した。

b) 流速: 岸壁直前にある本基地前面の流速を計測す るために、流速計を浮体模型前面の直前に設 置している.

c) 歪：浮体模型に作用する津波力を調べるために脚 上部に歪ゲージを表裹に各 2 枚、計 4 枚貼つ ている.

以下に、二次元水槽の基地模型、岸壁、計測器設 置状態を示す.

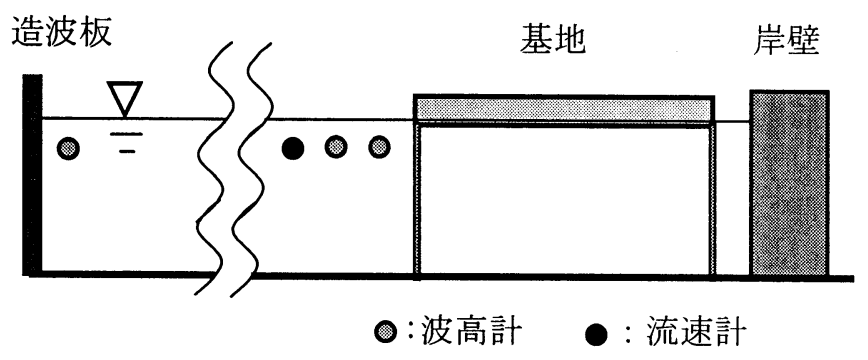

図-5 二次元水槽側方断面図

\section{4. 実験結果}

（1）津波波高と津波力の関係

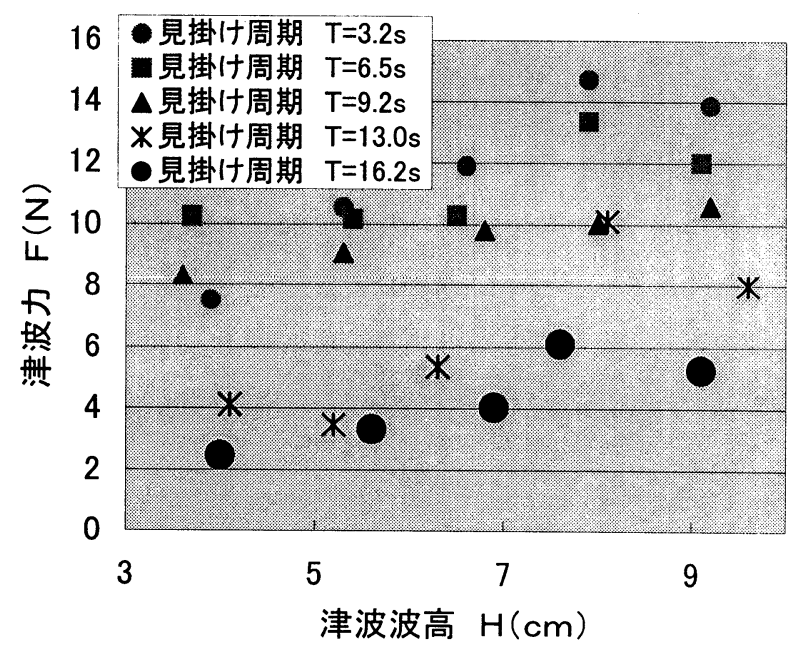

図-6＼cjkstart津波波高と津波力の関係

半浮体状態 (喫水 $1.2 \mathrm{~cm}$ の状態) の本浮体模型に設 定波高 $3.9 \mathrm{~cm}$ から $9.2 \mathrm{~cm}$ の津波を作用させた時の津波 波高と脚及び浮体模型に加わる津波力 $\mathrm{F}(\mathrm{N})$ の関係 
を図-6に示す。

a) 波高が高い津波ほど浮体模型に作用する津波力が 大きい。

b) 周期が短くなるにつれ津波力は大きくなる.

c) 沖合側 (造波機側)の脚は、岸壁側の脚と比較して 津波力の值が大きい。これは発生した津波が直接 模型前面および前面の脚に作用するためである思 われる。

\section{(2) 津波波高と抗力係数の関係}

ここでは抗力係数Cdをモリソン式により、実験で 明らかになった津波力と津波の最大流速の值から求 める.モリソン式のうち加速度が小さいので質量力 を無視し、抗力係数 (Cd值) を出している.

$$
\begin{gathered}
F=\frac{1}{2} \frac{w_{0}}{g} U^{2} C d A \\
\text { ただし、 } \\
F \quad \text { : 津波力 } \\
w_{0}: \text { 水の単位体積重量 } \\
g \quad \text { : 重力加速度 } \\
U \quad: \text { 流速 } \\
C d: \text { 抗力係数 } \\
A \quad \text { : 津波の作用する部分の面積 }
\end{gathered}
$$

以下図-7に津波波高と抗力係数の関係を示す.

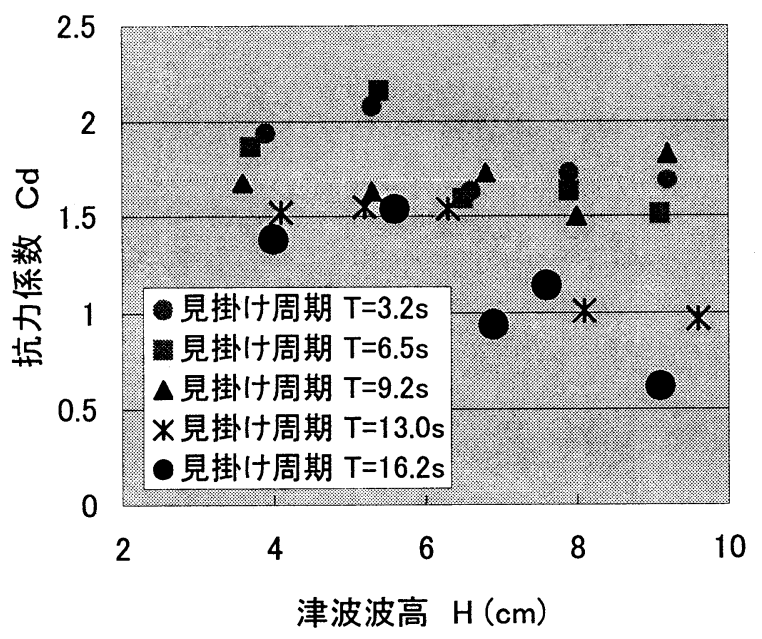

図-7 津波波高と抗力係数の関係

a)そのほとんどにおいて見掛け周期が長いほどCd值 は小さい。

b) 今回の実験での最高波高である $9.2 \mathrm{~cm}$ 前後の波に おいては、他の波高よりばらつきがある.
以上からCd值は1.0から2.00間でばらついており、 今回実験した津波波高においては1.5のあたりに集 中している. 実際の津波は、ここで言う周期がはる かに長いことを考えると、実験上で一番長い周期の $\mathrm{Cd}$ 值に意味があるといえる.従って津波力に対する 抗力係数は津波の見かけ周期が長いという前提で 1.5 程度である。なおこれはAdamsの言う流れ中の板 部材のCd值5) とほぼ等しいといえる.

また抗力係数Cdに対する評価は、図-8のReとCdの 関係のグラフを参考にする。これによると実験値は、 Cd值が1.0から2.00間でばらついており、概ね 1.5 に近い值である.

流れ中における板部材の抗力係数は、 SchlichtingによりRe数で整理されている ${ }^{6)}$. 本実験 結果を式(2) を用いて整理する。Re数は0.4〜 $1.8 \times$ $10^{4}$ であり、SchlichtingのRe数と抗力係数の関係よ り得られる抗力係数と同程度の值であった.

$$
\operatorname{Re}=\frac{U D}{v}
$$

$$
\text { ただし、 } U \text { : 流速 }
$$

$$
\begin{aligned}
& D: \text { 杭の径 } \\
& v: \text { 動粘性係数 }
\end{aligned}
$$

以下にSchlichtingの関係図に本実験の抗力係数 をプロットした図-8を示す.なおこれは、円柱部材 のReとCdの関係を示した既存のデータ上に、今回の 板部材の実験データをプロットした図である。

また想定した実機レベルにおいては、実際の海域 ではRe数が $10^{6}$ 程度であるので、Cd值は 1.0 程度をみ ればよいと思われる.

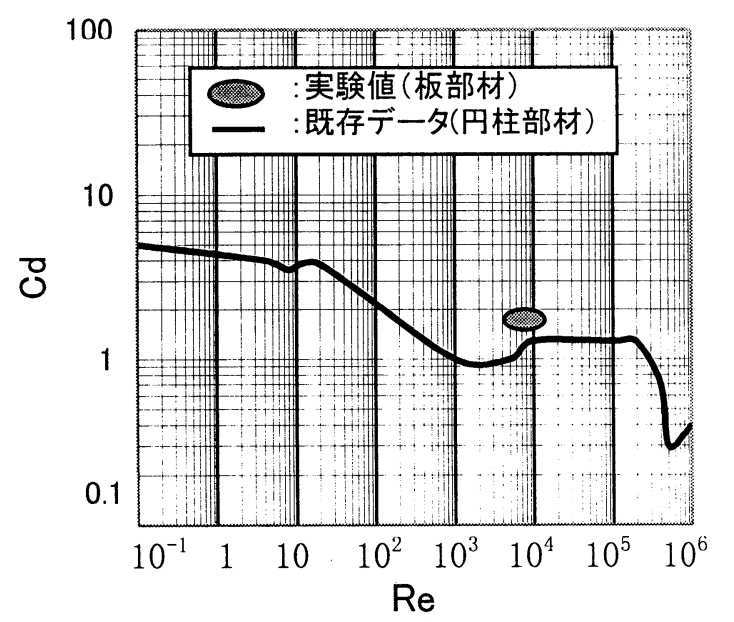

図-8 既存 $R e-C d$ 線 (円柱部材) 上の実験值 (板部材) プロット

（3）半浮体時における津波波高ピーク時の岸壁正 面の天端クリアランス 
半浮体状態 (喫水 $1.2 \mathrm{~cm}$ の状態) の浮体模型に設定 波高3. $9 \mathrm{~cm}$ から $9.2 \mathrm{~cm}$ の津波を発生させたときの岸壁 への作用高の様子を、X軸に天端クリアランス $\mathrm{f}$ $(\mathrm{cm}) 、 \mathrm{Y}$ 軸に津波波高 $\mathrm{H}(\mathrm{cm})$ をとり、津波の見掛け 周期が3. 2 秒から 16.2 秒においての関係図を以下に 示す.

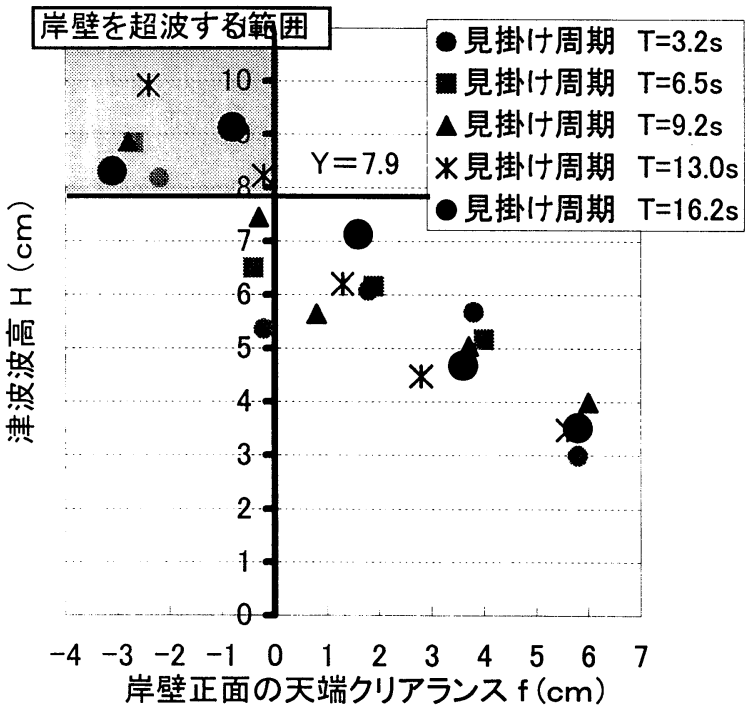

図-9 岸壁正面の天端クリアランスと津波波高の関係

a) 津波波高約 $7.9 \mathrm{~cm}$ 、見掛け周期 13.0 秒の来襲時に 波が岸壁を超えることが確認され、それ以上の波 高や見掛け周期においても越波する.

b) 浮体模型において波が越波するのは津波波高 $7.9 \mathrm{~cm}$ 、見掛け周期 9.2 秒の条件である.

以上のことから津波来襲時に本基地が半浮体状態 であるならば津波波高が $7.9 \mathrm{~cm}$ 、実際に想定してい る実機では3.0m未満までは耐えられるが、これ以上 には耐えられないことが確認できた。

今回の設定津波波高内においては、デッキクリア ランスを約 $10 \mathrm{~cm}$ (実機では約 $4 \mathrm{~m}$ )設けることにより津 波を回避できることが分かる.そのため本基地はQIP 方式の脚を取り入れている。一方、基地をドルフィ ン係留や岸壁へのボラードに緩係留することも考え られるが、両係留方式は実機において3mもの津波に 耐える事は難しい. しかも、狭い清水港にあって、 新たにこの基地のために広がった係留施設を設け海 域を占有することは適切でないと思われる。

しかしながら、QIP方式の脚を使用している本基 地は東海大地震発生後、津波来襲前5～6分間のうち にデッキ部を上昇させ脚式支持構造にすることで津 波を回避する必要がある。

本基地の平常時の接岸は清水港内の清水市岸壁の 一部とすると、予想津波高さはおおよそ3.0mであり 詳細な検討はまだだが十分対応できると考えている.

\section{5. おわりに}

本実験により以下のような結論が得られた。

（1）想定した実機において半浮体状態では津波波 高がおおよそ3.0m以下までなら耐えられるが、 それを超える津波においてはデッキを上昇させ 津波を回避する必要がある。さもないと、デッ キ部を越波(デッキウエットネス)し、スラミン グを起こし滑動や転倒の恐れがある.

（2）抗力係数に関しては、箱型の浮体と板形状の 脚から構成される本基地において、水粒子加速 度が小さいので津波力は質量力を無視してモリ ソン式により算定できる。この場合、模型レベ ルではCd值が 1.5 程度であるが、実機レベルで はレイノルズ数の関係から1.0程度をみればよ いと思う。

（3）現在検討されている海上防災支援拠点構想は、 被災後数日を要して曳航されてくるものである が、今回提案した我々の防災基地はこれとは異 なり被災直後から復旧支援に対応できるもので ある. 本基地は常設浮体であり、平常時には催 事場、防災啓蒙施設などに一般利用し、津波来 襲時には気象庁、津波センサーなどからの情報 を受け5〜6分でデッキを上昇させ津波を回避し、 その後直ちに復旧支援ができるコンセプトであ る.

以上の得られた知見より実現可能と思われ る.阪神・淡路大震災での教訓を、この様な形 で生かし東海地震に備えることはこの先、非 常に大きな意味を持つと考える。

\section{参考文献}

1）山本和宏他：海上移動式防災支援基地の研究, 平成11 年度海洋開発論文集, 第 15 巻, 土木学会, pp737一 742,1999

2）東海大学海洋学部編：四説海洋概論, 講談社, pp. 45 1997

3）関田欣治他：大規模浮体の孤立波に対する係留力と 上下応答の実験, 第14回海洋工学シンポジウム論文集, 日本造船学会, pp155-160, 1998

4) D.Goring et al.The Generation of Long Waves in the Laboratory, Coastal Engineering,ch.47,pp763-782,1980

5) A.J.Adams,Dynamics Of Fixed Marine Structures, Third edition, Atkins Oil Engineering Limited,Epsom,UK,pp308 $-312,1991$

6) H.Schlichting,Boundary-layer Theory,McGraw-Hill Book Company, $7^{\text {th }}$ ed.,pp134-143,1979 